\title{
Sex-Specific Heterosis in Line Crosses of Mice Selectively Bred for High Locomotor Activity
}

\author{
Robert M. Hannon - Thomas H. Meek • \\ Wendy Acosta $\cdot$ Robert C. Maciel $\cdot$ Heidi Schutz \\ Theodore Garland Jr.
}

Received: 7 July 2010/ Accepted: 8 December 2010/Published online: 24 December 2010

(C) The Author(s) 2010. This article is published with open access at Springerlink.com

\begin{abstract}
When populations with similar histories of directional selection are crossed, their offspring may differ in mean phenotype as compared with the average for the parental populations, often exhibiting enhancement of the mean phenotype (termed heterosis or hybrid vigor). We tested for heterosis in a cross of two replicate lines of mice selectively bred for high voluntary wheel running for 53 generations. Mice were paired to produce four sets of $\mathrm{F} 1$ offspring: two purebred High Runner (HR) lines and the hybrid reciprocal crosses. The purebred HR showed statistically significant, sex-dependent differences in body mass, wheel revolutions, running duration, mean running speed, and (controlling for body mass) organ masses (heart ventricles, liver, spleen, triceps surae muscle). Hybrid males ran significantly more revolutions than the purebred males, mainly via increased running speeds, but hybrid females ran intermediate distances, durations, and speeds, as compared with the purebred females. In both sexes, ventricles were relatively smaller in hybrids as compared with purebred HR. Overall, our results demonstrate differential and sex-specific responses to selection in the two HR lines tested, implying divergent genetic architectures underlying high voluntary exercise.
\end{abstract}

Keywords Artificial selection - Body size ·

Complementation - Experimental evolution - Heterosis . Hyperactivity · Voluntary exercise · Wheel running

Edited by Stephen Maxson.

R. M. Hannon - T. H. Meek · W. Acosta .

R. C. Maciel · H. Schutz - T. Garland Jr. $(\bowtie)$

Department of Biology, University of California, Riverside,

CA 92521, USA

e-mail: tgarland@ucr.edu

\section{Introduction}

Breeders of crops and livestock have known for centuries that matings between distantly related individuals often produce better offspring than those between closely related individuals (Darwin 1868). This phenomenon is commonly known as heterosis (since Shull 1914), or hybrid vigor, denoting the superiority of offspring. When inbred populations are crossed, the offspring will often exhibit mean values higher than those of the mid-parent level for any traits that have exhibited inbreeding depression, including aspects of Darwinian fitness (reproductive success, e.g., Falconer and Mackay 1996; Birchler et al. 2006). This is not always the case, however, as outbreeding depression can also occur in distantly related populations due to breakup of coadapted gene complexes that contribute to a phenotype affected by a high degree of epistasis (Lynch 1991, 1994; Burke and Arnold 2001; Birchler et al. 2006).

As noted by Mayr (1961), independent lines (populations) experiencing apparently identical directional selection will often respond at different paces and with different correlated traits. Although directional selection works to increase the frequency of favorable alleles while reducing the frequency of unfavorable alleles, the simultaneous effects of random genetic drift are indifferent to any particular allele's selective relevance. Therefore, drift potentially fixes alleles whose effects are neutral or even counter to what selection favors. As drift and mutation are stochastic processes, their effects will, on average, cause populations to diverge genetically, and the generation-togeneration response to directional selection will be contingent on existing genetic variation. For these reasons (and others), identical selection may often lead to "multiple solutions" in different populations (Garland and Rose 2009; Garland et al. 2011a) and when these populations are 
mixed, as during an intentional cross, heterosis for many traits will often occur (e.g., Ehiobu and Goddard 1990; Bult and Lynch 1996; reviews in Lynch and Walsh 1998; Lippman and Zamir 2007).

Heterosis has been documented for many traits, within many different species, such as high-temperature growth rate in yeast (Steinmetz et al. 2002), post-weaning success in pigs (Young et al. 1976), and mannose-binding lectin in humans (Hellemann et al. 2007). In house mice, heterosis has been observed for traits including food competition (Manosevitz 1972), motor behavior (Guttman et al. 1980), growth rates (Bhuvanakumar et al. 1985), body size (Lynch et al. 1986), litter size (Peripato et al. 2004), activity rhythms (Beau 1991), and nest-building behavior (Bult and Lynch 1996).

The primary purpose of the present study was to test for heterosis using two (of four) replicate lines of mice that have been bred for high voluntary wheel-running behavior (Swallow et al. 1998, 2005, 2009). Wheel running is a behavior that generally will involve aspects of both motivation and ability (Waters et al. 2008; Meek et al. 2009; Garland et al. 2011b). For example, an individual rodent that is highly motivated to run (e.g., because it is highly rewarding in a neurobiological sense) but lacks the inherent endurance capacity to do so simply will not be able to run as much as another individual with both high motivation and high ability. Rodent wheel running has been the subject of numerous studies, with goals ranging widely across behavior, physiology, and genetics (e.g., Slonaker 1912; de Kock and Rohn 1971; Holloszy and Smith 1987; Belke and Garland 2007). Despite a century of study, precisely what wheel running in laboratory rodents represents remains controversial (Mather 1981; Sherwin 1998; Garland et al. 2011b). Heterosis has been observed for wheel-running behavior (and other aspects of locomotor activity, e.g., exploratory behavior) when inbred strains of mice were crossed (Bruell 1964a, b).

The crosses necessary to study heterosis also allowed us to test for line differences. On average, the four replicate High Runner (HR) lines run 2.5- to 3.0-fold more revolutions/day as compared with four non-selected control (C) lines, a differential that has been maintained from approximately generation 16 to the time of the present study at generation 53 (Middleton et al. 2008; Swallow et al. 2009; Kolb et al. 2010). The nature of this selection limit is as yet unknown, but does not appear to be simply an exhaustion of additive genetic variance for wheel running (unpublished results). Phenotypically, the selection limit may be related to availability of lipids to fuel the many hours of running that occur during each 24-h period (Gomes et al. 2009; Kolb et al. 2010; Meek et al. 2010). Whatever the precise phenotypic characteristics that underlie the selection limit, if a cross between two HR lines results in hybrid vigor, then selection applied to a population derived from such a line cross would have the potential to break through the prevailing selection limit (e.g., Bult and Lynch 2000). In addition to measures of wheel running, we report data for masses of four organs, at least three of which (heart ventricles, calf muscles, liver) may have important roles during endurance running (e.g., see Dumke et al. 2001; Garland et al. 2002; Swallow et al. 2005; Rezende et al. 2006c; Meek et al. 2009; and references therein).

\section{Methods}

Animals

Mice used in this study were from an ongoing selection experiment for high voluntary wheel running. Full details of the selection experiment are found in Swallow et al. (1998), and only a brief synopsis is presented here. The original progenitors were 224 mice of the outbred, genetically variable (e.g., see Carter et al. 1999) Hsd:ICR strain of house mice (Mus domesticus). This population was randomly mated for two generations and then divided into eight closed lines, four of which were deemed high runner (lab designations HR 3,6,7,8) and four control (C 1,2,4,5). A minimum of ten pairs from each line were used to propagate the subsequent generations. Pregnant dams are given a breeder diet (Harlan Teklad, Madison, WI, Mouse Breeder Diet [S-2335] 7004) through weaning. At other times, standard chow (Harlan Teklad, Madison, WI, Rodent Diet [W] 8604) and water are available ad libitum. Pups are weaned at 21 days of age. Each generation, at 6-8 weeks of age, mice are individually housed with access to a Wahman-type running wheel (circumference $=1.12 \mathrm{~m}$ ) for 6 days, during which daily wheel running is monitored by a computer-automated system. The selection criterion is the mean number of revolutions run on days 5 and 6 of the 6 -day test. In the four HR lines, the highest-running male and female from each family are chosen as breeders (i.e., within-family selection). In addition, second-highest running males and females are chosen to provide backup pairings. In the four control lines (C), two males and two females are randomly chosen from each family without regard to wheel running. Within all lines, breeders are randomly paired, excluding sibling mating.

Selected lines 7 and 8 were chosen for this study due to the absence of the mini-muscle allele, which affects numerous traits, including wheel running and organ masses (see Garland et al. 2002, Swallow et al., 2005; Rezende et al. 2006a, c; Hannon et al. 2008; Hartmann et al. 2008; Middleton et al. 2008; Gomes et al. 2009). All line 7 and line 8 breeders (see previous paragraph) from generation 53 were repaired to produce mice for the present study (i.e., 
second litters). Sires were housed individually from time of removal from first pairing to time of second pairing. Dams were housed 3-4 to a cage from time of weaning of first litter to time of pairing for this experiment.

Due to the within-family selection method used to choose breeders for the selection experiment, the breeders for the present experiment usually had three siblings (one of the same sex, two of the opposite sex) also included in the experiment. Therefore, mice were repaired using the following guidelines. Sibling mating was disallowed and all females were mated with a novel male. Considering two siblings of the same sex, one sibling was randomly chosen to be mated with a mouse from the same line, while the other sibling was mated to the other line. For families represented by other than four (3 or 5) siblings, the odd mouse was randomly assigned as a breeder.

This protocol produced a total of 43 breeding pairs: 11 pairs were purebred line $7 \times$ line 7 ; 10 were purebred line $8 \times$ line $8 ; 11$ were male line $7 \times$ female line 8 hybrids; 11 were male line $8 \times$ female line 7 hybrids. Purebred offspring of the replicate selected lines $(7 \times 7$ and $8 \times 8)$ were used because direct comparison to parental individuals could be compromised due to possible generational effects, which can be substantial (e.g., see figures in Swallow et al. 1998, 2009; Middleton et al. 2008; Kolb et al. 2010). Reciprocal crosses for the hybrids were conducted to test for parental effects. Eighteen days after pairing, the male was removed if the female was visibly pregnant; otherwise, he remained with the female until she appeared pregnant. Mice were weaned at 21 days of age and housed 4 per cage by sex and cross type. Total sample sizes were 171 females and 166 males for wheel-running traits, with the breakdown by cross type as follows: 47 female and 38 male for line $7 \times$ line $7 ; 42$ female and 48 male for line $8 \times$ line $8 ; 38$ female and 37 male for male line $7 \times$ female line 8 hybrids; 45 female and 43 male for male line $8 \times$ female line 7 hybrids. For organ masses, total sample sizes were 177 females (176 for ventricle mass) and 166 males (165 for ventricle mass and triceps surae mass).

Measurement of wheel running and organ masses

F1s were wheel-tested in the same manner as in the regular selection experiment (described above). Rooms were controlled for temperature $\left(\sim 22^{\circ} \mathrm{C}\right)$ and photoperiod 12:12 light/dark cycle (lights on 0700). Wheels were checked daily to ensure freedom of rotation. Wheel running was monitored with a computer-automated system and revolutions were recorded in 1-min bins (intervals). Wheel running was quantified as means for days 5 and 6 of the 6-day test (Swallow et al. 1998). Following previous studies, we analyzed means for total revolutions per day, the number of 1-min intervals per day with at least one revolution (minutes/day), the mean speed when running (revolutions/ minutes), and the highest single 1-min interval per day (e.g., Swallow et al. 1998; Hannon et al. 2008; Kelly et al. 2010a, b). We also analyzed body mass at the start of the wheel trial.

Following wheel testing, mice were returned to standard cages without wheels, housed 4 per cage. Approximately 7 days following wheel testing, mice were sacrificed by $\mathrm{CO}_{2}$ inhalation in batches to allow for harvesting of organs and muscle tissue. Mean age at sacrifice was $69 \pm 3$ $( \pm S D)$ days. Following sacrifice, mice were weighed and dissected to determine masses of organs that have potential relevance for exercise physiology. The heart was detached and ventricles were removed from the atria and connecting blood vessels. Ventricles were blotted to remove any excess blood prior to weighing. The liver was excised followed by the spleen, then the right and left triceps surae muscles [which include the lateral and medial heads of the gastrocnemius, soleus, and the plantaris, as described in Carter et al. (1999)]. Wet masses of all tissues were recorded to the nearest $0.001 \mathrm{~g}$ on an electronic balance (Denver Instruments, Denver CO, USA, model M-220).

\section{Statistical analyses}

To test for differences in wheel running, body mass, and organ masses, a two-way analysis of covariance model (ANCOVA) was applied using the MIXED procedure in SAS (version 9.1; SAS Institute, Cary, NC, USA). All analyses used age as a covariate. Analyses of organ masses used body mass as an additional covariate. Analyses of wheel-running traits did not include body mass as a covariate, but did use a measure of wheel freeness. To measure wheel freeness, each wheel was accelerated to a constant velocity, then the number of revolutions spun until stopping was recorded. For analyses, wheel freeness was transformed by raising measured values to the 0.4 power to obtain a more homogeneous spread of values. Deviations from linearity were not apparent in plots of the wheel-running traits versus transformed wheel freeness, and preliminary analyses indicated that the interaction between group and transformed wheel freeness were not statistically significant (all $P>0.08)$. Therefore, this interaction term was not included in final statistical models. Family was a random effect, nested within cross type. Preliminary analyses combined the sexes and tested for effects of cross type, sex, and the cross type * sex interaction. Because we found significant interactions (e.g., for revolutions/day, $P=0.0012$; see Results), subsequent analyses were done separately by sex.

The hybrid groups were expected to exhibit greater variance than the parental types. Therefore, we considered a range of models that allowed for different variances 
Table 1 Statistical comparisons of body mass, wheel running, and organ masses (with body mass as a covariate) separated by sex

\begin{tabular}{|c|c|c|c|c|c|c|}
\hline & $7 \times 7$ vs. $8 \times 8$ & $\begin{array}{l}\text { Female } \\
\text { Hybrid versus } \\
\text { purebred }\end{array}$ & $7 \times 8$ vs. $8 \times 7$ & $7 \times 7$ vs. $8 \times 8$ & $\begin{array}{l}\text { Male } \\
\text { Hybrid versus } \\
\text { purebred }\end{array}$ & $7 \times 8$ vs. $8 \times 7$ \\
\hline $\begin{array}{l}\text { Body mass at start } \\
\text { of wheel access }\end{array}$ & $\begin{array}{l}F(1,27)=22.79 \\
\boldsymbol{P}<\mathbf{0 . 0 0 0 1}(-)\end{array}$ & $\begin{array}{l}F(1,27)=3.16 \\
P=0.0869(-)\end{array}$ & $\begin{array}{l}F(1,27)=0.18 \\
P=0.6754(-)\end{array}$ & $\begin{array}{l}F(1,28)=8.27 \\
P=\mathbf{0 . 0 0 7 6}(-)\end{array}$ & $\begin{array}{l}F(1,28)=2.53 \\
P=0.1229(-)\end{array}$ & $\begin{array}{l}F(1,28)=4.34 \\
P=0.0464(-)\end{array}$ \\
\hline Revolutions/day & $\begin{array}{l}F(1,27)=10.48 \\
P=\mathbf{0 . 0 0 3 2}^{\mathbf{a}}(+)\end{array}$ & $\begin{array}{l}F(1,27)=0.03 \\
P=0.8618^{\mathrm{a}}(-)\end{array}$ & $\begin{array}{l}F(1,27)=0.31 \\
P=0.5853^{\mathrm{a}}(+)\end{array}$ & $\begin{array}{l}F(1,27)=1.93 \\
P=0.1759(-)\end{array}$ & $\begin{array}{l}F(1,27)=12.23 \\
P=\mathbf{0 . 0 0 1 6}(+)\end{array}$ & $\begin{array}{l}F(1,27)=1.41 \\
P=0.2457(+)\end{array}$ \\
\hline Minutes/day & $\begin{array}{l}F(1,27)=0.26 \\
P=0.6163(+)\end{array}$ & $\begin{array}{l}F(1,27)=0.00 \\
P=0.9879(-)\end{array}$ & $\begin{array}{l}F(1,27)=0.53 \\
P=0.4735(-)\end{array}$ & $\begin{array}{l}F(1,27)=14.98 \\
P=\mathbf{0 . 0 0 0 6}(-)\end{array}$ & $\begin{array}{l}F(1,27)=3.27 \\
P=0.0819(+)\end{array}$ & $\begin{array}{l}F(1,27)=1.58 \\
P=0.2195(+)\end{array}$ \\
\hline Mean speed & $\begin{array}{l}F(1,27)=15.92 \\
\boldsymbol{P}=\mathbf{0 . 0 0 0 5}(+)\end{array}$ & $\begin{array}{l}F(1,27)=0.03 \\
P=0.8666(-)\end{array}$ & $\begin{array}{l}F(1,27)=2.30 \\
P=0.1412(+)\end{array}$ & $\begin{array}{l}F(1,27)=4.54 \\
P=0.0423(+)\end{array}$ & $\begin{array}{l}F(1,27)=10.09 \\
\boldsymbol{P}=\mathbf{0 . 0 0 3 7}(+)\end{array}$ & $\begin{array}{l}F(1,27)=0.65 \\
P=0.4263(+)\end{array}$ \\
\hline Max speed & $\begin{array}{l}F(1,27)=14.09 \\
P=\mathbf{0 . 0 0 0 8}(+)\end{array}$ & $\begin{array}{l}F(1,27)=0.00 \\
P=0.9935(-)\end{array}$ & $\begin{array}{l}F(1,27)=1.10 \\
P=0.3037(+)\end{array}$ & $\begin{array}{l}F(1,27)=0.77 \\
P=0.3877(+)\end{array}$ & $\begin{array}{l}F(1,27)=7.65 \\
P=\mathbf{0 . 0 1 0 1}(+)\end{array}$ & $\begin{array}{l}F(1,27)=0.22 \\
P=0.6427(+)\end{array}$ \\
\hline $\begin{array}{l}\text { Body mass at } \\
\text { dissection }\end{array}$ & $\begin{array}{l}F(1,29)=23.66 \\
\boldsymbol{P}<\mathbf{. 0 0 0 1}(-)\end{array}$ & $\begin{array}{l}F(1,29)=5.18 \\
P=0.0305(-)\end{array}$ & $\begin{array}{l}F(1,29)=2.87 \\
P=0.1012(-)\end{array}$ & $\begin{array}{l}F(1,28)=15.33 \\
\boldsymbol{P}=\mathbf{0 . 0 0 0 5}(-)\end{array}$ & $\begin{array}{l}F(1,28)=6.66 \\
P=\mathbf{0 . 0 1 5 4}(-)\end{array}$ & $\begin{array}{l}F(1,28)=0.82 \\
P=0.3739(-)\end{array}$ \\
\hline Ventricle mass & $\begin{array}{l}F(1,29)=6.59 \\
P=\mathbf{0 . 0 1 5 7}(+)\end{array}$ & $\begin{array}{l}F(1,29)=10.18 \\
P=\mathbf{0 . 0 0 3 4}(-)\end{array}$ & $\begin{array}{l}F(1,29)=0.00 \\
P=0.9906(+)\end{array}$ & $\begin{array}{l}F(1,28)=0.61 \\
P=0.4402(+)\end{array}$ & $\begin{array}{l}F(1,28)=4.64 \\
P=0.0399(-)\end{array}$ & $\begin{array}{l}F(1,28)=0.01 \\
P=0.9274(-)\end{array}$ \\
\hline Liver mass & $\begin{array}{l}F(1,29)=3.13 \\
P=0.0875(-)\end{array}$ & $\begin{array}{l}F(1,29)=3.32 \\
P=0.0789(-)\end{array}$ & $\begin{array}{l}F(1,29)=0.65 \\
P=0.4263(-)\end{array}$ & $\begin{array}{l}F(1,28)=11.18 \\
\boldsymbol{P}=\mathbf{0 . 0 0 2 4}(-)\end{array}$ & $\begin{array}{l}F(1,28)=1.64 \\
P=0.2106(-)\end{array}$ & $\begin{array}{l}F(1,28)=0.04 \\
P=0.8471(+)\end{array}$ \\
\hline Spleen mass & $\begin{array}{l}F(1,29)=10.62 \\
\boldsymbol{P}=\mathbf{0 . 0 0 2 8}(-)\end{array}$ & $\begin{array}{l}F(1,29)=3.19 \\
P=0.0845(+)\end{array}$ & $\begin{array}{l}F(1,29)=1.52 \\
P=0.2274(-)\end{array}$ & $\begin{array}{l}F(1,28)=25.31 \\
\boldsymbol{P}<\mathbf{. 0 0 0 1}(-)\end{array}$ & $\begin{array}{l}F(1,28)=0.00 \\
P=0.9527(+)\end{array}$ & $\begin{array}{l}F(1,28)=1.13 \\
P=0.2966(+)\end{array}$ \\
\hline Triceps Surae mass & $\begin{array}{l}F(1,29)=21.53 \\
\boldsymbol{P}<\mathbf{. 0 0 0 1 ( - )}\end{array}$ & $\begin{array}{l}F(1,29)=0.35 \\
P=0.5598(-)\end{array}$ & $\begin{array}{l}F(1,29)=0.88 \\
P=0.3555(-)\end{array}$ & $\begin{array}{l}F(1,28)=13.76 \\
P=\mathbf{0 . 0 0 0 9}(-)\end{array}$ & $\begin{array}{l}F(1,28)=0.01 \\
P=0.9327(-)\end{array}$ & $\begin{array}{l}F(1,28)=0.21 \\
P=0.6521(-)\end{array}$ \\
\hline
\end{tabular}

${ }^{a}$ Full model (\#6 as described in Methods) did not converge for female revolutions/day, so results are for a reduced model (\#5 in Methods) All analyses used age as a covariate. Analyses of wheel-running traits also used a measure of wheel freeness (see Methods) $P$ values significant after controlling for multiple comparisons (see Methods) are in bold

Signs after $P$ values indicate direction of effect: for purebreds, minus indicates $7<8$, plus indicates $7>8$; for reciprocal hybrids, minus indicates $7 \times 8<8 \times 7$, plus indicates $7 \times 8>8 \times 7$; for hybrids versus purebreds, minus indicates hybrid $>$ purebred, plus indicates purebred $>$ hybrid

among families within types and/or among individuals within families (i.e., the residual variance). Specifically, we considered models with (1) a single estimate for residual variance, (2) a single estimate for residual variance and a single estimate for variance among families (nested random effect), (3) a single estimate for residual variance and separate estimates of family variance for each of the four cross types, (4) a different residual variance for each cross type and no variance among families, (5) a different residual variance for each cross type and a single estimate of variance among families, (6) a different residual variance for each cross type and separate estimates of family variance for each cross type. We used a priori contrasts to compare the two parental types (i.e., test for line differences), the two reciprocal hybrid crosses (test for parental effects), and the two parental groups with the two hybrid groups (test for heterosis). In general, significance levels for these contrasts were similar across the six models listed above. For simplicity and consistency, we report results only for the most parameter-rich model, i.e., number (6) above. In some cases, traits were transformed to improve normality of residuals.

Because we performed a number of tests on closely related data, our Type I error rate for the entire experiment may exceed the nominal 5\% alpha level. Therefore, we performed a positive false discovery rate (pFDR) analysis using the QVALUE package (Version 1.1; Storey 2002) for $\mathrm{R}$ (Version 2.8.0; R Core Development Team 2008), allowing for $5 \%$ false significant results $(\mathrm{pFDR}=0.05$ ). Based on analysis of the $60 P$ values presented in Table 1, those $<0.016$ can be considered significant, and we emphasize those results.

\section{Results}

In preliminary analyses, we found significant sex * cross type interactions for revolutions/day $(P=0.0012)$, minutes/day $(P=0.0140)$, and maximum speed in any 1 -min interval $(P=0.0255)$, but not for mean speed 
$(P=0.0850)$ or body mass $(P=0.7866)$. Therefore, subsequent analyses were done separately by sex.

Females

After adjusting for multiple comparisons, purebred females from line 7 ran significantly more revolutions per day $(P=0.0032)$, at higher mean $(P=0.0005)$ and maximum speeds $(P=0.0008)$, but not for more minutes per day $(P=0.6163)$, as compared with line 8 females (Tables 1, 2; Fig. 1). Line 7 females were significantly smaller than those from line 8 (Tables 1,2). Controlling for variation in body mass, lines 7 and 8 differed significantly for ventricle, spleen, and triceps sure mass, but not liver mass (Tables 1, 2; Fig. 2).

Female hybrids were intermediate between the purebred lines for body mass at the start of wheel access and for all running traits (Fig. 1; Tables 1, 2). Female hybrids had significantly smaller ventricles $(P=0.0034)$ than purebreds after adjusting for body mass. Hybrids from the two reciprocal cross populations were not significantly different for any trait (Tables 1, 2; Figs. 1, 2).

\section{Males}

Purebred males from HR lines 7 and 8 differed significantly for minutes/day of wheel running, but not for revolutions/day, mean speed or max speed (Tables 1, 2; Fig. 1). Purebred males from line 8 were significantly larger than those from line 7 , and they also had significantly larger livers, spleens, and triceps surae muscles (Fig. 2; Tables 1, 2).

Unlike female hybrids, as compared with the mean for purebred lines, male hybrids showed a significant increase in revolutions per day $(P=0.0016)$, mean speed $(P=0.0037)$, and maximum speed $(P=0.0101)$, but did not differ in body mass at the start of wheel access (Tables 1, 2). Consistent with females, male hybrids from the reciprocal crosses $(7 \times 8$ vs. $8 \times 7)$ were not significantly different for any trait (Tables 1, 2; Figs. 1, 2).

\section{Discussion}

Results of our crosses between two replicate lines bred for high voluntary wheel running, intended primarily to examine heterosis, also show that the two lines differ for a number of traits, often in a sex-specific fashion. For example, revolutions run per day-the target of selective breeding-were higher in purebred HR line 7 than 8 for females (14,607 vs. 10,878, respectively, 2-tailed $P=0.0032)$, but not for males $(9,123$ vs. 11,257 , $P=0.1759$ ) (Fig. 1; Tables 1, 2). Moreover, the patterns

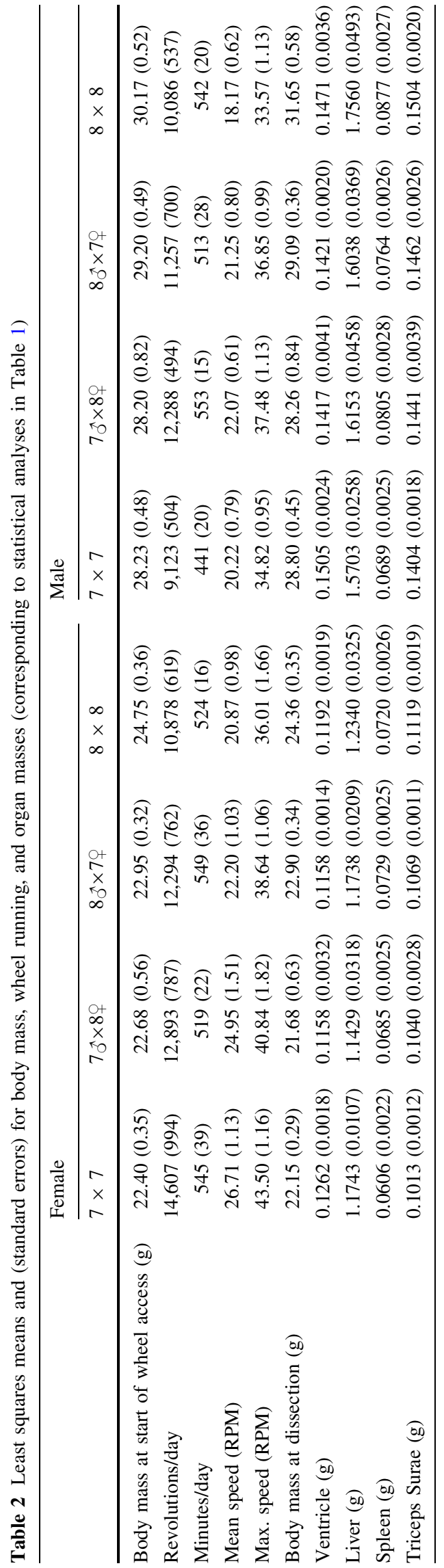



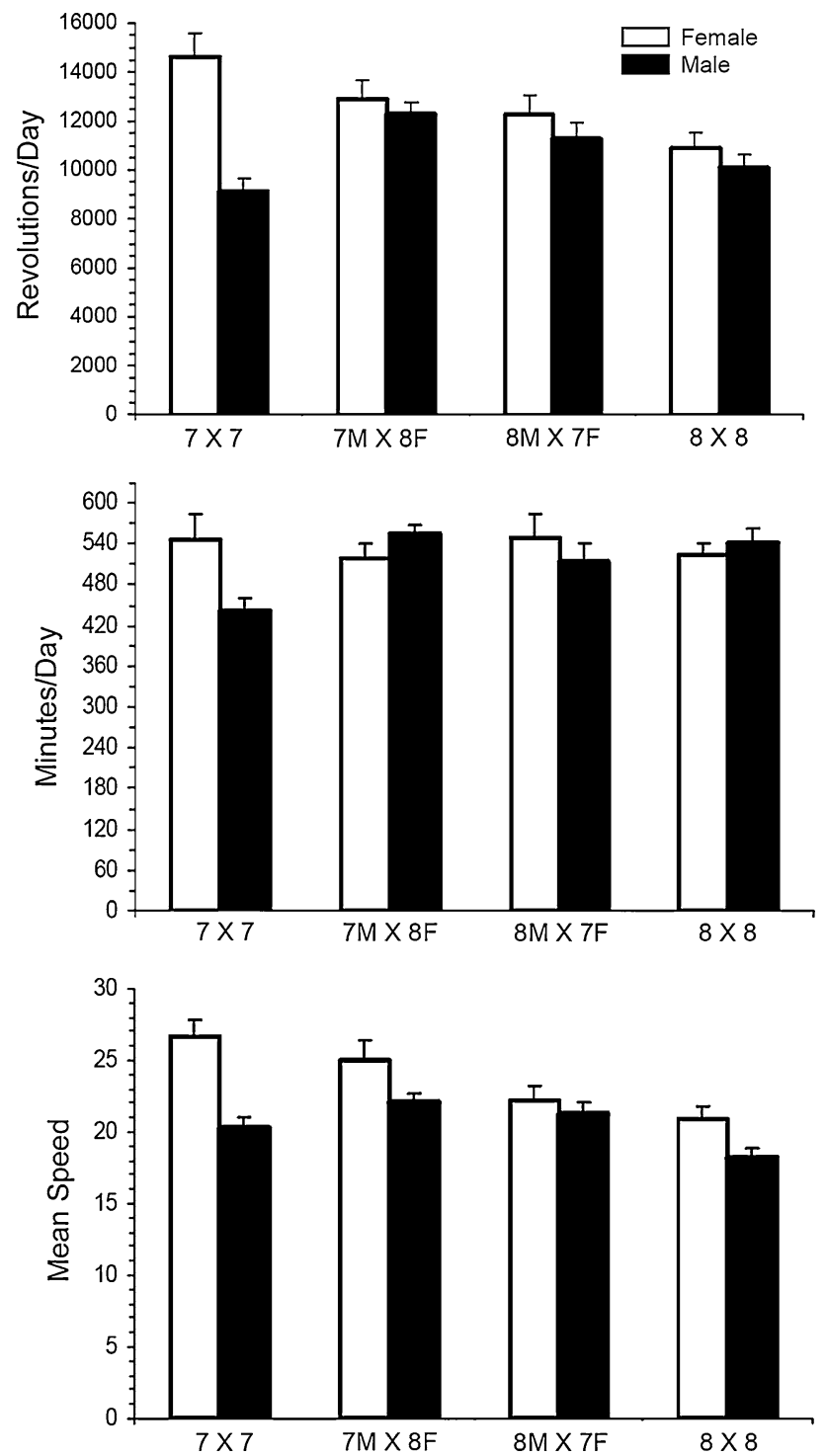

Fig. 1 Wheel-running activity during days 5 and 6 of a 6-day exposure to wheels (1.12 m circumference) attached to standard housing cages. Values are least squares means + SEs from analysis of covariance models in SAS Procedure Mixed (see text and Table 1 for statistical results). $7 \times 7$ and $8 \times 8$ denote purebred mice from two different HR lines bred for high voluntary wheel running (Swallow et al. 1998). Values in between these are for reciprocal crosses. See Table 2 for numerical values

of heterosis that we identified differ between males and females. Therefore, we separate much of the subsequent discussion by sex. It is important to note that the higher wheel running of females than males in line 7 is not peculiar to this generation (e.g., see Garland et al. 2011a for results from generation 43).

\section{Males}

For males, examination of the two components of wheel revolutions/day indicates that the two HR lines have

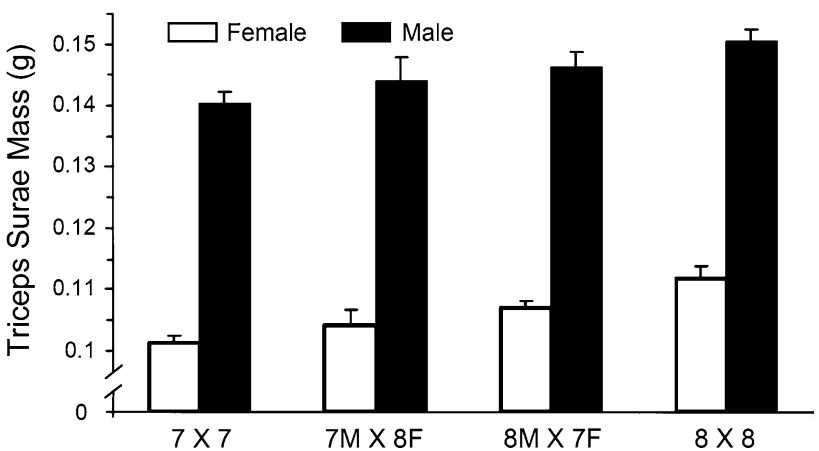

Fig. 2 Triceps surae muscle mass, adjusted for body mass. Values are least squares means + SEs from analysis of covariance models in SAS Procedure Mixed (see Table 1 for statistical results and Table 2 for numerical values). Note broken $Y$-axis to emphasize differences among groups. $7 \times 7$ and $8 \times 8$ denote purebred mice from two different HR lines bred for high voluntary wheel running (Swallow et al. 1998). Values in between these are for reciprocal crosses

responded differently to artificial selection (Fig. 1; Tables 1,2). Line 8 males ran substantially more minutes/ day as compared with line 7 (542 vs. $441 \mathrm{~min} /$ day), but the direction of this differential was reversed for mean running speed ( 18.17 vs. 20.02 revolutions/min). The end result was no statistical difference in revolutions/day $(10,086$ vs. 9,123), thus demonstrating approximate functional equivalence achieved by "multiple solutions" in response to selective breeding (e.g., Endler et al. 2001; Spitschak et al. 2007; see also Swallow et al. 2009; Garland et al. 2011a). Line 7 males were smaller than those of line 8, and also had significantly smaller body-mass adjusted spleens, livers, and triceps surae muscles (Tables 1, 2; Fig. 2), but whether this is causally related to the differences in running behavior is unclear (see also Garland et al. 2002).

Consistent with the partial evolutionary independence of average running speed and duration found in the present study, within an advanced intercross mapping population of HR line \#8 and inbred C57BL/6J, two statistically significant QTL were detected for average running speed on days 5 plus 6 , and a different QTL was detected for time spent running on days 5 and 6 (Kelly et al. 2010b), although a formal test for epistasis was not performed. Similarly, a QTL analysis of an F2 population from a cross between relatively high-running $\mathrm{C} 57 \mathrm{~L} / \mathrm{J}$ and low-running $\mathrm{C} 3 \mathrm{H} / \mathrm{HeJ}$ inbred strains found two QTL for wheel-running speed, one of which did not colocalize with the single QTL identified for duration (Lightfoot et al. 2008), although a subsequent paper detected considerable epistasis by use of a full genome epistasis scan for all possible interactions of QTL between each pair of 20 chromosomes (Leamy et al. 2008).

Hybrid males showed a significant increase in revolutions/day over purebred males (hybrid vigor), caused mainly by higher running speed, with a trend also for more time spent running (Fig. 1). This result demonstrates that 
the underlying genetic architecture of high wheel running in males differs between these two HR lines (e.g., Bult and Lynch 1996). In contrast to the results for wheel running, hybrids were intermediate to the parental groups for relative liver, spleen, and triceps surae muscle masses. It is interesting that these lower-level traits do not follow the same pattern of heterosis as the target of selection, which could be explained by their not being functionally necessary to support the higher levels of wheel running and/or by a change in their genetic correlation with wheel running in the cross populations (e.g., see Eisen 1975). In previous publications that reported masses for these organs, no consistent, statistically significant differences were found in comparisons of the four High Runner and four control lines (Dumke et al. 2001; Garland et al. 2002; Swallow et al. 2005; Rezende et al. 2006c; Meek et al. 2009).

\section{Females}

Unlike males, purebred line 7 females ran significantly more revolutions/day than line 8 females, almost entirely because the former ran faster, with no statistical difference in duration of running (Fig. 1; Tables 1, 2). Also unlike males, hybrid females were intermediate between the two parental phenotypes for both revolutions/day and speed. In spite of the differences from males, overall these comparisons again indicate different genetic responses to selection.

As with males, females of line 7 were smaller than line 8 and had smaller size-adjusted spleens and triceps surae. In contrast to males, line 7 females had relatively larger hearts than their line-8 counterparts (Tables 1,2 ), which could contribute to their higher running speeds via positive effects on endurance (Meek et al. 2009) or maximal aerobic capacity (Rezende et al. 2006b, c, 2009). Arguing against this, however, hybrid females had relatively smaller heart ventricles $(P=0.0034)$ than either purebred line, but exhibited intermediate levels of wheel running (Fig. 1; Tables 1, 2).

\section{Parental effects}

In a reciprocal cross between HR line 8 and a control line, we found parent-of-origin effects in the F1 for both body mass and wheel running (R. M. Hannon, S. A. Kelly, B. K. Keeney, J. L. Malisch, and T. Garland, Jr., unpublished results). Similarly, in a cross between HR line 8 and inbred C57BL/6J, we found parent-of-origin effects on body composition and wheel-running traits in a fourthgeneration intercross population (Kelly et al. 2010a). In the present cross, however, we found no such effects that were statistically significant. The lack of such effects in the present cross may reflect the fact that the two replicate HR lines studied here are more similar, both phenotypically and genetically, than for a control line or C57BL/6J vs. HR line 8.

Summary and future directions

The line crosses presented here demonstrate different responses to selection for high voluntary wheel running in two (of four total) replicate HR lines, as well as sex-by-line interactions in the response to selection. In addition, the two HR lines not studied here have shown an increase in the frequency of a Mendelian recessive allele that causes a $50 \%$ reduction in hindlimb muscle mass and increased wheel-running speed, among many other identified pleiotropic effects (Garland et al. 2002; Swallow et al. 2005; Rezende et al. 2006a; Hannon et al. 2008; Middleton et al. 2008; Gomes et al. 2009). The "mini-muscle" phenotype was never detected in the two lines studied here, again demonstrating different genetic responses to selection. Thus, overall, results of the long-term selection experiment reinforce the concept that directional selection favoring a particular phenotype, and hence altering the frequencies of alleles that affect the phenotype, will occur simultaneously with other evolutionary processes, especially random genetic drift in the relatively small populations used for rodent selection experiments (e.g., Eisen 1975; Swallow et al. 2009).

Hormonal differences may contribute to the line (or sex: Lightfoot 2008) differences we observed. For example, it has been shown previously that HR lines have higher circulating corticosterone (CORT) concentrations than $\mathrm{C}$, and that differences among replicate lines are also statistically significant (Malisch et al. 2007, 2009). As suggested elsewhere (Malisch et al. 2008), organisms with elevated corticosterone levels could have higher available energy and/or motivation to perform during exercise such as wheel running (Dallman et al. 1993; Pecoraro et al. 2006). However, whether HR lines 7 and 8 show consistent differences in baseline CORT or in levels during wheel running is not yet known (see Malisch et al. 2007, 2009).

Our results show some clear examples of sex-specific heterosis, as has occasionally been reported in the literature. White et al. (1970) report heterosis involving body mass in mice, with both sexes experiencing heterosis, but one sex showing it to a greater degree. Line crosses involving body mass in beef cattle and poultry (Stonaker 1963), fecundity in Drosophila (Brown and Bell 1960), and survival in swine (Cox 1960) also showed one sex to exhibit a greater degree of heterosis. However, the pattern of sex-specific heterosis reported in this study seems to be rare. Unlike the examples cited, we show cases (Fig. 1) in which the $\mathrm{F} 1$ of one sex exhibits clear heterosis, whereas the F1 of the other is intermediate between the phenotypic means of the parental populations. 
The mechanisms underlying the cases of sex-specific heterosis that we observed are not yet apparent. Using a backcross between a different HR line (\#3) and inbred C57BL/6J, Nehrenberg et al. (2010) reported several sexspecific QTL, including for aspects of wheel running. That study probably underestimates the magnitude of such effects, because the cross design used did not allow examination of markers on the sex chromosomes. Kelly et al. (2010b) included markers on the $X$ chromosome in a QTL study that used a large advanced intercross line (G4) population originated from a reciprocal cross between HR line \#8 (one of the two used here) and C57BL/6J, but did not any detect any QTL on the X chromosome nor any sexspecific QTL. As noted in the Introduction, Leamy et al. (2008) detected a large amount of epistasis using a full genome scan of SNP markers in an F2 population of mice derived from a cross of two inbred strains, and some of the epistatic interactions involved markers on the $\mathrm{X}$ chromosome. To date, no study of mouse wheel-running QTL has included markers on the $\mathrm{Y}$ chromosome. Molecular imprinting is widespread in the mouse genome (Searle and Beechey 1978; Cattanach and Kirk 1985; Cattanach 1986), and sex-specific molecular imprinting (Hager et al. 2008) could potentially account for the differential heterosis we see between the sexes in the F1 hybrids.

Experimental evidence has shown that both dominance and over-dominance play a role in heterosis, with some involvement of epistasis, although the relative contribution of each of these mechanisms is still unclear (Birchler et al. 2006; Lippman and Zamir 2007) and is likely to vary among organisms, strains, and traits. Additionally, epistatic interactions among loci can also play a significant role in heterosis. For example, in an F2 population of mice derived from a cross of two strains exhibiting large differences in wheel running (C57L/J, high active; $\mathrm{C} 3 \mathrm{H} / \mathrm{HeJ}$, low active), a full-genome epistasis scan for all possible interactions of QTL between each pair of 20 chromosomes indicated that epistatic interactions contributed an average of $26 \%$ of the total genetic variation for the three measures of daily wheel running (total distance, duration, and average speed) (Leamy et al. 2008). As with most other studies of heterosis in rodent behavior (e.g., Bruell 1964a, b; Lynch et al. 1986; Bult and Lynch 1996, 2000), the present study provides no evidence as to which mechanism(s) account(s) for the observed instances of heterosis. Nonetheless, our results do indicate that crossing of replicate selected lines can yield offspring that exceed what was an apparent selection limit, as in Bult and Lynch (1996). Given that heterosis for wheel running was only observed in male hybrids, it raises the interesting possibility that female mice might be closer to a true selection limit as compared with males. This suggests that further selection on a population descended from the hybrids (Bult and Lynch 2000) might be able to break the limit for males but not females.

Acknowledgments We thank S. A. Kelly for helpful discussions and comments on the manuscript. Supported by NSF grant IOB0543429 to T.G.

Open Access This article is distributed under the terms of the Creative Commons Attribution Noncommercial License which permits any noncommercial use, distribution, and reproduction in any medium, provided the original author(s) and source are credited.

\section{References}

Beau J (1991) Activity rhythms in inbred mice. I. Genetic analysis with recombinant inbred strains. Behav Genet 21:117-130

Belke TW, Garland T Jr (2007) A brief opportunity to run does not function as a reinforcer for mice selected for high daily wheelrunning rates. J Exp Anal Behav 88:199-213

Bhuvanakumar CK, Lynch CB, Roberts RC, Hill WG (1985) Heterosis among lines of mice selected for body weight 1 . Growth Theor Appl Genet 71:44-51

Birchler JA, Yao H, Chudalayandi S (2006) Unraveling the genetic basis of hybrid vigor. PNAS 103:12957-12958

Brown WMP, Bell AE (1960) Genetic analysis of a "plateaued" population of Drosophila melanogaster. Genetics 46:407-425

Bruell JH (1964a) Inheritance of behavioral and physiological characters of mice and the problem of heterosis. Am Zool 4: $125-138$

Bruell JH (1964b) Heterotic inheritance of wheelrunning in mice. J Comp Physiol Psychol 58:159-163

Bult A, Lynch CB (1996) Multiple selection responses in house mice bidirectionally selected for thermoregulatory nest-building behavior: crosses of replicate lines. Behav Genet 26:439-446

Bult A, Lynch CB (2000) Breaking through artificial selection limits of an adaptive behavior in mice and the consequences for correlated responses. Behav Genet 30:193-206

Burke JM, Arnold ML (2001) Genetics and the fitness of hybrids. Annu Rev Genet 35:31-52

Carter PA, Garland T Jr, Dohm MR, Hayes JP (1999) Genetic variation and correlations between genotype and locomotor physiology in outbred laboratory house mice (Mus domesticus). Comp Biochem Physiol A 123:155-162

Cattanach BM (1986) Parental origin effects in mice. J Embryol Exp Morp 97:137-150

Cattanach BM, Kirk M (1985) Differential activity of maternally and paternally derived chromosome regions in mice. Nature 315: 496-498

Cox DF (1960) The relation between sex and survival in swine. J Hered 51:284-288

Dallman MF, Strack AM, Akana SF, Bradbury MJ, Hanson ES, Scribner KA, Smith M (1993) Feast and famine: critical role of glucocorticoids with insulin in daily energy flow. Front Neuroendocrinol 14:303-347

Darwin C (1868) The variation of animals and plants under domestication, 2nd edn. John Murray, London

de Kock LL, Rohn I (1971) Observations on the use of the exercisewheel in relation to the social rank and hormonal conditions in the bank vole (Clethrionomys glareolus), and the Norway lemming (Lemmus lemmus). Z Tierpsychol 29:180-195

Dumke CL, Rhodes JS, Garland T Jr, Maslowski E, Swallow JG, Wetter AC, Cartee GD (2001) Genetic selection of mice for high 
voluntary wheel running: effect on skeletal muscle glucose uptake. J Appl Physiol 91:1289-1297

Ehiobu NG, Goddard ME (1990) Heterosis in crosses between geographically separated populations of Drosophila melanogaster. Theor Appl Genet 80:569-575

Eisen EJ (1975) Population size and selection intensity effects on long-term selection response in mice. Genetics 79:305-323

Endler JA, Basolo A, Glowacki S, Zerr J (2001) Variation in response to artificial selection for light sensitivity in guppies (Poecilia reticulata). Am Nat 158:36-48

Falconer DS, Mackay TFC (1996) Introduction to quantitative genetics, 4th edn. Longman, Essex

Garland T Jr, Rose MR (eds) (2009) Experimental evolution: concepts, methods, and applications of selection experiments. University of California Press, Berkeley

Garland T Jr, Kelly SA, Malisch JL, Kolb EM, Hannon RM, Keeney BK, Van Cleave SL, Middleton KM (2011a) How to run far: Multiple solutions and sex-specific responses to selective breeding for high voluntary activity levels. Proc R Soc B. doi: 10.1098/rspb.2010.1584

Garland T Jr, Schutz H, Chappell MA, Keeney BK, Meek TH, Copes LE, Acosta W, Drenowatz C, Maciel RC, van Dijk G, Kotz CM, Eisenmann JC (2011b) The biological control of voluntary exercise, spontaneous physical activity and daily energy expenditure in relation to obesity: human and rodent perspectives. J Exp Biol 214:206-229

Garland T Jr, Morgan TM, Swallow JG, Rhodes JS, Girard I, Belter JG, Carter PA (2002) Evolution of a small-muscle polymorphism in lines of house mice selected for high activity levels. Evolution 56:1267-1275

Gomes FR, Rezende EL, Malisch JL, Lee SK, Rivas DA, Kelly SA, Lytle C, Yaspelkis BB III, Garland T Jr (2009) Glycogen storage and muscle glucose transporters (GLUT-4) of mice selectively bred for high voluntary wheel running. J Exp Biol 212:238-248

Guttman R, Lieblich I, Frankel E (1980) Level and shape of sequences of motor behavior in inbred and hybrid mice. Behav Genet 10:251-261

Hager R, Cheverud JM, Leamy LJ, Wolf JB (2008) Sex dependent imprinting effects on complex traits in mice. BMC Evol Biol 8:303

Hannon RM, Kelly SA, Middleton KM, Kolb EM, Pomp D, Garland T Jr (2008) Phenotypic effects of the "mini-muscle" allele in a large HR $\times$ C57BL/6J mouse backcross. J Hered 99:349-354

Hartmann J, Garland T Jr, Hannon RM, Kelly SA, Muñoz G, Pomp D (2008) Fine mapping of "Mini-Muscle", a recessive mutation causing reduced hind-limb muscle mass in mice. J Hered 99:679-687

Hellemann D, Larsson A, Madsen HO, Bonde J, Jarløv JO, Wiis J, Faber T, Wetterslev J, Garred P (2007) Heterozygosity of mannose-binding lectin (MBL2) genotypes predicts advantage (heterosis) in relation to fatal outcome in intensive care patients. Hum Mol Genet 16:3071-3080

Holloszy JO, Smith EK (1987) Effects of exercise on longevity of rats. Fed Proc 46:1850-1853

Kelly SA, Nehrenberg DL, Hua K, Gordon RR, Garland T Jr, Pomp D (2010a) Parent-of-origin effects on voluntary exercise levels and body composition in mice. Physiol Genom 40:111-120

Kelly SA, Nehrenberg DL, Peirce JL, Hua K, Steffy BM, Wiltshire T, Manuel Pardo, de Villena F, Garland T Jr, Pomp D (2010b) Genetic architecture of voluntary exercise in an advanced intercross line of mice. Physiol Genom 42:190-200

Kolb EM, Kelly SA, Middleton KM, Sermsakdi LS, Chappell MA, Garland T Jr (2010) Erythropoietin elevates $\mathrm{VO}_{2} \max$ but not voluntary wheel running in mice. J Exp Biol 213:510-519

Leamy LJ, Pomp D, Lightfoot JT (2008) An epistatic genetic basis for physical activity traits in mice. J Heredity 99:639-646
Lightfoot JT(2008) Sex hormones' regulation of rodent physical activity: a review. Int J Biol Sci 4:126-132

Lightfoot JT, Turner MJ, Pomp D, Kleeberger SR, Leamy LJ (2008) Quantitative trait loci (QTL) for physical activity traits in mice. Physiol Genom 32:401-408

Lippman ZB, Zamir D (2007) Heterosis: revisiting the magic. Trends Genet 23:60-66

Lynch M (1991) The genetic interpretation of inbreeding depression and outbreeding depression. Evolution 45:622-629

Lynch CB (1994) Evolutionary inferences from genetic analyses of cold adaptation in laboratory and wild populations of the house mouse, Mus domesticus. In: Boake CRB (ed) Quantitative genetic studies of behavioral evolution. University of Chicago Press, Chicago, pp 278-301

Lynch M, Walsh B (1998) Genetics and analysis of quantitative traits. Sinauer Associates, Sunderland (MA)

Lynch CB, Roberts RC, Hill WG (1986) Heterosis among lines of mice selected for body weight. 3. Thermoregulation. Genet Res 48:95-100

Malisch JL, Saltzman W, Gomes FR, Rezende EL, Jeske DR, Garland $\mathrm{T}$ Jr (2007) Baseline and stress-induced plasma corticosterone concentrations of mice selectively bred for high voluntary wheel running. Physiol Biochem Zool 80:146-156

Malisch JL, Breuner CW, Gomes FR, Chappell MA, Garland T Jr (2008) Circadian pattern of total and free corticosterone concentrations, corticosteroid-binding globulin, and physical activity in mice selectively bred for high voluntary wheelrunning behavior. Gen Comp Endocrinol 156:210-217

Malisch JL, Kelly SA, Bhanvadia A, Blank KM, Marsik RL, Platzer EG, Garland T Jr (2009) Lines of mice with chronically elevated baseline corticosterone are more susceptible to a parasitic nematode infection. Zoology 112:316-324

Manosevitz M (1972) Behavioral heterosis: food competition in mice. J Comp Physiol Psychol 79:46-50

Mather JG (1981) Wheel-running activity: a new interpretation. Mamm Rev 11:41-51

Mayr E (1961) Cause and effect in biology. Science 134:1501-1506

Meek TH, Lonquich BP, Hannon RM, Garland T Jr (2009) Endurance capacity of mice selectively bred for high voluntary wheel running. J Exp Biol 212:2908-2917

Meek TH, Eisenmann JC, Garland T Jr (2010) Western diet increases wheel running in mice selectively bred for high voluntary wheel running. Int J Obesity 34:960-969

Middleton KM, Kelly SA, Garland T Jr (2008) Selective breeding as a tool to probe skeletal response to high voluntary locomotor activity in mice. Integr Comp Biol 48:394-410

Nehrenberg DLS, Wang RM, Hannon GarlandT Jr, Pomp D (2010) QTL underlying voluntary exercise in mice: interactions with the "mini muscle" locus and sex. J Hered 101:42-53

Pecoraro N, Dallman MF, Warne JP, Ginsberg AB, Laugero KD, la Fleur SE, Houshyar H, Gomez F, Bhargava A, Akana SF (2006) From Malthus to motive: how the HPA axis engineers the phenotype, yoking needs to wants. Prog Neurobiol 79:247-340

Peripato AC, De Brito RA, Matioli SR, Pletscher LS, Vaughn TT, Cheverud JM (2004) Epistasis affecting litter size in mice. J Evol Biol 17:593-602

Rezende EL, Garland T Jr, Chappell MA, Malisch JL, Gomes FR (2006a) Maximum aerobic performance in lines of Mus selected for high wheel-running activity: effects of selection, oxygen availability, and the mini-muscle phenotype. J Exp Biol 209:115-127

Rezende EL, Kelly SA, Gomes FR, Chappell MA, Garland T Jr (2006b) Effects of size, sex, and voluntary running speeds on cost of locomotion in lines of laboratory mice selectively bred for high wheel-running activity. Physiol Biochem Zool 79:83-99 
Rezende EL, Gomes FR, Malisch JL, Chappell MA, Garland T Jr (2006c) Maximal oxygen consumption in relation to subordinate traits in lines of house mice selectively bred for high voluntary wheel running. J Appl Physiol 101:477-485

Rezende EL, Gomes FR, Chappell MA, Garland T Jr (2009) Running behavior and its energy cost in mice selectively bred for high voluntary locomotor activity. Physiol Biochem Zool 82:662-679

Searle AG, Beechey CV (1978) Complementation studies with mouse translocations. Cytogenet Cell Genet 20:282-303

Sherwin CM (1998) Voluntary wheel running: a review and novel interpretation. Anim Behav 56:11-27

Shull AF (1914) Duplicate genes for capsule form in Bursa bursapastoris. Zeitschr F Ind Abst Vererb 12:97-149

Slonaker JR (1912) The normal activity of the albino rat from birth to natural death, its rate of growth and the duration of life. J Anim Behav 2:20-42

Spitschak M, Langhammer M, Schneider F, Renne U, Vanselow J (2007) Two high-fertility mouse lines show differences in component fertility traits after long-term selection. Reprod Fertil Dev 19:815-821

Steinmetz LM, Sinha H, Richards DR, Spiegelman JI, Oefner PJ, McCusker JH, Davis RW (2002) Dissecting the architecture of a quantitative trait locus in yeast. Nature 416:326-330
Stonaker HH (1963) A genetic hypothesis for sex-mating system interactions in growth of cattle and poultry. J Anim Sci 22:320-325

Swallow JG, Carter PA, Garland T Jr (1998) Artificial selection for increased wheel-running behavior in house mice. Behav Genet 28:227-237

Swallow JG, Rhodes JS, Garland T Jr (2005) Phenotypic and evolutionary plasticity of organ masses in response to voluntary exercise in house mice. Integr Comp Biol 45:426-437

Swallow JG, Hayes JP, Koteja P, Garland T Jr (2009) Selection experiments and experimental evolution of performance and physiology. In: Garland T Jr, Rose MR (eds) Experimental evolution: concepts methods and applications of selection experiments. University of California Press, Berkeley, pp 301-351

Waters RP, Renner KJ, Pringle RB, Summers CH, Britton SL, Koch LG, Swallow JG (2008) Selection for aerobic capacity affects corticosterone, monoamines and wheel-running activity. Physiol Behav 93:1044-1054

White JM, Eisen EJ, Legates JE (1970) Sex-heterosis interaction, heterosis and reciprocal effects among mice selected for body weight. J Anim Sci 31:289-295

Young LD, Johnson RK, Omtvedt IT, Walters LE (1976) Postweaning performance and carcass merit of purebred and twobreed cross pigs. J Anim Sci 42:1124-1132 